Андріянова Н. М., канд. політ. наук

Шпура М. I., канд. військ. наук, ст. наук. співроб.

(0000-0002-7115-2445);

Ковальчук П. А.

(0000-0002-3350-6003);

Голопатюк Л. С., канд. військ. наук

Центр воєнно-стратегічних досліджень Національного університету оборони України імені Івана Черняховського, Київ

\title{
Українсько-польська оборонна співпраця: визначення пріоритетних подальших напрямів
}

Резюме. Стаття присвячена дослідженню основних напрямів оборонної співпраці між Україною та Польщею на сучасному етапі. Визначені пріоритетні напрями подальшого оборонного співробітництва Польщі та України, враховуючи суперечності на основі тлумачення історичних подій.

Ключові слова: оборонна співпраця; стратегічне партнерство; Польща; Україна.

Постановка проблеми: 3 початку проголошення незалежності України в 1991 p. Польща була найближчим і найважливішим стратегічним партнером України. Це довели роки лобіювання євроінтеграційного курсу України в європейських інституціях до і після вступу Польщі до лав повноправних членів НАТО у 1999 р. та постійна допомога Україні під час ринкових і демократичних реформ.

Для наповнення змістом стратегічного партнерства Польщі та України сторони створили певну інституційну структуру партнерства. Це постійно діючі механізми реалізації та координації стратегічних інтересів у рамках партнерства (Консультативний комітет президентів України та Республіки Польща, УкраїнськоПольська змішана комісія 3 питань торгівлі та економічного співробітництва, українськопольська та польсько-українська парламентські групи, Постійна українськопольська конференція 3 питань європейської інтеграції, українсько-польський, польськоукраїнський форуми).

Варто відзначити, що згідно 3 офіційними заявами та документами для України визначено стратегічними партнерами понад 15 країн, але фактично відносини 3 цими державами не виходять за межі констатації намірів. Отже для України $\epsilon$ надзвичайно важливою співпраця 3 Республікою Польща (РП) та ії підтримка.

Водночас 32015 року спостерігається послаблення інтересу польської громадськості до України та деяке “охолодження” відносин на фоні історичних протиріч.

Аналіз основних досліджень і публікацій. Зазначена тема широко досліджується як в наукових джерелах, так і в публіцистичній літературі в українській $\mathrm{i}$ зарубіжній, особливо польській. Під час дослідження значної уваги приділялось дослідженням польських авторів А. Шептицького [1], К. Федоровіца [2] та українських - А. Гетьманчук [3], С. Шестопалова [4], Є. Бабакової [5], В. Сердюка [10] та ін., які досліджували питання співробітництва України і Польщі та можливі причини “охолодження" їх відносин. Уваги заслуговує проєкт Міжнародного центру перспективних досліджень за підтримки Міжнародного Вишеградського фонду: "Україна та країни Вишеградської четвірки: на шляху до кращого взаєморозуміння та добросусідства" [10], де багато уваги приділено питанням розбіжності України та Польщі, причинам i шляхам покращення кризи добросусідства, проблемам двосторонніх відносин.

Метою статті с дослідження основних напрямів оборонної співпраці України та Польщі на основі аналізу документів, наукової і публіцистичної літератури та визначення пріоритетних напрямів подальшої співпраці.

Виклад основного матеріалу. Основою для військової співпраці між Україною та Польщею є угода між Міністерством оборони Республіки Польща та Міністерством оборони України про співробітництво у військовій галузі, яку було підписано 3 лютого 1993 року, під час візиту міністра національної оборони Польщі Я. Онишкевича в Києві. У документі викладається перелік сфер співробітництва, з яких найважливішими були визначені питання роззброєння, організаційні питання щодо функціонування оборонних відомств двох країн і 
співробітництва на рівні оборонної промисловості [12].

У вступі до угоди було зазначено, що “співробітництво не стосуватиметься інтересів третіх держав” [13]. Для України цей припис був досить доречним, особливо з огляду на те, що в першій половині дев'яностих років Україна активно прагнула побудувати відносини із Заходом для зрівноваження впливу Росії [2].

Україна шукала підтримки на заході, зокрема від Польщі. Означену угоду з часом було доповнено документами, що стосуються: подальшого розвитку співробітництва (Київ, 1996);

співпраці в галузі військової підготовки персоналу (Київ, 1996);

співпраці щодо основ взаємного повітряного руху військових повітряних суден України та Республіки Польща у повітряному просторі обох держав (Демблін, 1994);

взаємних поставок озброєння, військової техніки та військово-технічних послуг (Київ, 1996);

науково-технічного співробітництва

(Варшава, 1996);

створення спільної військової частини для участі в міжнародній миротворчій $\mathrm{i}$ гуманітарній діяльності під егідою міжнародних організацій (Варшава, 1997); технічної угоди про участь національних контингентів в українськопольському батальйоні у міжнародній миротворчій операції в Косово (Яворів, 2000) [4].

Польща вже надає консультативну допомогу в здійсненні військової реформи у напрямі адаптації до стандартів НАТО. У межах "Програми польських збройних сил щодо підтримки імплементації Цілей партнерства 2006 для України", підписаної 9 серпня 2006 року начальниками генеральних штабів Збройних Сил України та Війська Польського, проводяться стажування офіцерів командної ланки Міністерства оборони та Генерального Штабу України у відповідних інституціях польських 3С.

Двостороння співпраця в оборонній сфері між Україною і Польщею на сьогодні спирається на підписану 2 грудня 2016 року відповідну міжурядову угоду та додаток до неї [14]. Зокрема, ними передбачено тісне співробітництво ВПК обох країн - тут $\epsilon$ обопільний інтерес. Конкретним виявом такої співпраці може стати розроблення та виробництво спільних зразків озброєнь.
Як зазначається, метою документа $є$ створення договірно-правової бази для розвитку співробітництва між Сторонами в оборонній сфері на принципах взаємності.

Зокрема, Угода створює правові підстави для розширення українськопольської співпраці в оборонній галузі, зокрема за напрямами:

військовий зв'язок та інформаційні системи;

проведення науково-дослідних робіт для

потреб збройних сил;

оборонна політика і планування;

логістичне забезпечення збройних сил;

проведення військових інженерно-

технічних робіт;

військова інфраструктура;

розроблення, модернізація, виготовлення i постачання оборонного обладнання, співпраця у галузі оборонної промисловості;

операції сил спеціального призначення;

інші напрями співробітництва за взаємною згодою Сторін [15].

У 2007 році керівниками військових відомств України, Республіки Польща та Литовської Республіки було підписано Лист намірів щодо створення литовсько-польськоукраїнського миротворчого батальйону “ЛИТПОЛУКРБАТ”.

У 2009 році за результатами міжурядових переговорів польська сторона виступила 3 ініціативою щодо посилення формата співробітництва та запропонувала сформувати литовсько-польсько-українську бригаду “ЛИТПОЛУКРБРИГ”.

4 лютого 2015 року Верховна Рада України ратифікувала Угоду між урядами України, Литви i Польщі щодо створення спільної військової частини LITPOLUKRBRIG.

ЛИТПОЛУКРБРИГ - бригада $є$ першим довготривалим i постійним проєктом зі створення спільної військової частини. Вона $\epsilon$ прикладом багатосторонньої військової інтеграції на основі стандартів НАТО, але поза межами офіційного членства України в Альянсі.

5 жовтня 2017 року Міністр оборони України генерал армії України С. Полторак взяв участь у підписанні Угоди між Урядом Литовської Республіки, Урядом Республіки Польща та Кабінетом Міністрів України про внесення змін до Угоди між Урядом Литовської Республіки, Урядом Республіки Польща та Кабінетом Міністрів України щодо 
створення спільної військової частини. “Ця угода змінює форму цієї бригади. Віднині бригада зможе брати участь у заходах, які $\epsilon$ необхідними тоді, коли мир перебуває під загрозою. Це добрий знак, який дасть змогу нашим народам, а насамперед бригаді, діяти заради безпеки Центрально-Східної Свропи", - заявив $з$ цього приводу А. Мацеревич [16].

Підрозділ вже брав участь у складі багатонаціонального навчання "Anakonda-16" у 2016 р. На полігоні Нова Демба (Польща) навчалося майже 1200 військовослужбовців та цивільних працівників із п'яти країн світу. Зокрема, ЛИТПОЛУКРБРИГ, підрозділи ЗС США, механізований i танковий батальйони ЗС Республіки Польща, український аеромобільний взвод, рота територіальної оборони. Навчальні завдання успішно виконала і механізована бригада ЗС Угорщини [17].

Тренування "Brave Band" $\epsilon$ першим заходом бойової підготовки у складі штабу ЛИТПОЛУКРБРИГ 3 часу іiі офіційного відкриття 25 січня 2016 року. Під час "Brave Band" військовослужбовці відпрацьовували питання виконання гуманітарної операції.

Участь українських воїнів у навчаннях ЛИТПОЛУКРБРИГ $є$ надзвичайно важливим не лише для українців, але і для поляків та литовців, адже українці зараз діляться своїм бойовим досвідом, отриманим на своїй території, про що з повагою заявив польський президент А. Дуда під час свого візиту до штабу ЛИТПОЛУКРБРИГ [18].

Необхідно відмітити, що після 2015 року в українсько-польських відносинах простежується певна криза, спричинена, переважно, історичними суперечками після того, як Верховна Рада України визнала воїнів УПА учасниками боротьби за незалежність у 2015 році, а польський сейм у 2016 році визнав Волинську трагедію геноцидом польського народу. Деякі експерти називають останні роки найгіршим періодом в історії українсько-польських відносин після 1989 року [9].

Утім, за прогнозами аналітиків є надія на покращення стосунків [9]. Особливо, слід відмітити заходи, що заплановані на річницю Варшавських подій, яка відбудеться 2020 р. та піл час яких українці та поляки мають продемонструвати здатність до співпраці. Відзначення цієї річниці та правильне інформаційне супроводження подій надасть змогу відновити попередні дружні відносини, повернути минулу завзяту підтримку України
Польщею на міжнародній арені, якої ми зараз так потребуємо.

Відповідно дослідженої проблематики, Стратегічне партнерство Польщі та України потребує зосередження на таких напрямах:

1. Співробітництво в широко визначеній сфері оборони (військова співпраця, співпраця спецслужб і співпраця в рамках військової промисловості).

2. Суспільний діалог i партнерство (співпраця засобів масової інформації, молодіжні обміни, партнерства громад, дослідження громадської думки, сприйняття українських мігрантів у польському суспільстві).

3. Конструктивний історичний діалог, спрямований на поліпшення стосунків (відповідна політична риторика, діалог істориків i політичних діячів, вшанування пам'ятників i могил, дозвіл на археологічні розкопки та ексгумацію тіл, побудова спільних музеїв, пам'ятників спільної українсько-польської історії).

4. Подальший пріоритет участі в ЛИТПОЛУКРБРИГ. Польща у співпраці 3 іншими партнерами могла би лобіювати розширення участі України у безпекових ініціативах $\mathrm{CC}$ на додаток до посиленої ролі у вже передбачених форматах (поліцейські місії, бойові групи тощо).

5. Участь України у формуванні бойових тактичних груп Європейських сил швидкого реагування (польський військовий контингент складає основу "Балтійської" бойової групи) у складі військових підрозділів Вишеградської групи та України.

Висновки. Незважаючи на деяку кризу у відносинах із західним сусідом, певні суперечки в історичній площині польськоукраїнська співпраця має істотне значення для України, адже Республіка Польща є однією 3 перших країн, яка різко засудила вторгнення російських військ на українську територію і анексію Криму. Керівництво РП виступає за надання Україні міжнародної підтримки, матеріальної, фінансової та військовотехнічної допомоги з боку ЄС, НАТО і МВФ. У рамках цієї політики Варшава розробляє план заходів, спрямованих на підтримування проведення реформ в Україні, в адміністративній, безпековій, оборонній, економічній, фінансовій, судовій, гуманітарній та освітній сферах.

Польща $є$ стратегічним партнером України, i цінність цього партнерства відзначають обидві сторони: воно є впливовим 
фактором економічної і політичної стабілізації не лише в Центрально-Східній Європі, а й на континенті загалом.

Подальші наукові дослідження слід зосередити на дослідженні напрямів розвитку і удосконалення оборонної співпраці Польщі та України.

\section{СПИСОК ВИКОРИСТАНОЇ ЛІТЕРАТУРИ}

1. Szeptycki Andrzej. Poland-Ukraine relations. Revista UNISCI Journal. № 40 (Enero / January 2016). p. 57-76.

2. Fedorowicz K. Polityka Polski wobec Rosji, Ukrainy i Białorusi w latach 1989-2010. Poznań:Wydawnictwo naukowe. UAM. 2011. 340 p.

3. Гетьманчук А. Україна-Польща: партнерство без патронату і передумов. 24 березня, 2017. Дзеркало тижня. URL: https://dt.ua/in ternal/ukrayina-polschapartnerstvo-bez-patronatu-i-peredumov-_.html (дата звернення: 25.08.2019).

4. Шестопалов C.С. Українсько-польське військове співробітництво. Чорноморський літопис. 2014. Випуск 10. С. 66-71.

9. Бабакова Е. Что ожидает польско-украинские отношения в 2019 году? 31.12.2018. Eastbook. URL: https://www.eastbook.eu/ru/2018/12/31/babakowastosunki-polsko-ukrainskie-w-2019/ (дата звернення: 25.08.2019).

10. Сердюк В. До Польщі без Порошенка: чого очікує Варшава від президента Зеленського. Свропейська правда Міжнародна безпека та євроінтеграція України. URL:

https://www.eurointegration.com.ua/experts/2019/05/6/709 5834/ (дата звернення: 25.08.2019).

11. Ukraine-Poland relations. Ukraine and V4 countries: promoting better understanding. International Centre for Policy Studies. URL: http://icps.com.ua/assets/uploads/images/files/ua_pl_relati ons icps.pdf (дата звернення: 25.08.2019).
12. Сардачук П. Д. Сагадак О. П. Україна в двосторонніх міжнародних відносинах (кінець XX початок XXI століть): навч.-довід. посібник. Київ : Вид-во Свроп. ун-ту, 2005. $328 \mathrm{c}$.

13. Угода між Міністерством оборони України та Міністерством національної оборони Республіки Польща про військове співробітництво. URL: http://zakon4.rada.gov.ua/laws/show/616_191 (дата звернення: 25.08.2019).

14. Генеральна угода між Кабінетом Міністрів України та Урядом Республіки Польща про співробітництво у сфері оборони від 02.12.2016. URL: https://zakon.rada.gov.ua/laws/show/en/616_002-16251 (дата звернення: 25.08.2019).

15. Україна і Польща уклали військову угоду. URL: https://ukr.media/politics/283947/ (дата звернення: 25.08.2019)

16. Україна, Польща і Литва уклали тристоронню угоду про співпрацю у сфері функціонування ЛитовськоПольсько-Української бригади. URL: https://goo.gl/xg9Wnq (дата звернення: 25.08.2019).

17. Військові навчання “Анаконда-2016” завершилися у Польщі. УНН - Українські Національні новини. Інформаційне агентство. URL: https://www.unn.com.ua/uk/news/1580020-viyskovinavchannya-anakonda-2016-zavershilisya-u-polschi (дата звернення: 25.08.2019).

18. Polish President stresses the importance of military cooperation between Poland and Ukraine. URL: https://uawire.org/polish-president-stresses-theimportance-of-military-cooperation-between-poland-andukraine\# (дата звернення: 25.08.2019).

19. Polish Foreign Policy Strategy 2017-2021. URL: https://www.msz.gov.pl/resource/0c98c3b2-9c5d-4c428761-f7827134ee76:JCR (дата звернення: 25.08.2019).

20. Ukraine's new president may improve Polish-Ukrainian relations. URL: https://polandin.com/42359257/ukrainesnew-president-may-improve-polishukrainian-relationsexpert (дата звернення: 25.08.2019).

Стаття надійшла до редакційної колегії 17.12.2019

\section{Ukrainian-Polish defence cooperation: determining priority directions}

\section{Annotation}

Since the beginning of Ukraine's declaration of independence in 1991, Poland has been Ukraine's closest and the most important strategic partner.

In order to fill the content of the strategic partnership between Poland and Ukraine, the parties have created a certain institutional structure for the partnership. These are permanent mechanisms for implementing and coordinating strategic interests within the partnership (Advisory Committee of the Presidents of Ukraine and Poland, Ukrainian-Polish Joint Commission on Trade and Economic Cooperation, Ukrainian-Polish and PolishUkrainian Parliamentary Groups, Permanent Ukrainian-Polish Conference on Issues European integration, Ukrainian-Polish, Polish-Ukrainian forums).

But after 2015, there has been a certain crisis in Ukrainian-Polish relations, caused mainly by historical disputes after the Verkhovna Rada of Ukraine recognized the UPA soldiers as participants in the struggle for independence in 2015, and the Polish Seimas in 2016 recognized the Volyn tragedy as a genocide of the Polish people. Some experts have called recent years the worst period in the history of Ukrainian-Polish relations since 1989.

Despite these developments, Polish-Ukrainian cooperation has great importance for Ukraine, as the Republic of Poland is one of the first countries convicted the invasion of Russian troops into Ukrainian territory and annexation of Crimea. The leadership of Poland stands for providing Ukraine with international support, material, financial and military-technical assistance from the EU, NATO and the IMF.

Therefore, the article identifies priority areas for further defense cooperation between Poland and Ukraine on the basis of the analysis, taking into account contradictions based on the interpretation of historical events. Which, in our opinion, is an urgent and very important issue both for resolving the Donbas conflict and for Ukraine's EuroAtlantic integration.

Keywords: defense cooperation; strategic partnership; Poland; Ukraine. 